\title{
Indocyanine green-mediated photothrombosis for choroidal neovascularization in angioid streaks
}

\author{
Fototrombose mediada por indocianina verde para o tratamento de \\ neovascularização de coróide em estrias angióides
}

\author{
Fernando Korn Malerbi ${ }^{1}$ \\ Sheau Jiun Huang' 2 \\ Fabio Bom Aggio $^{3}$ \\ Edenilson Carvalho Jr. ${ }^{4}$ \\ PedroPaulo Bonomo ${ }^{5}$ \\ Michel Eid Farah ${ }^{6}$
}

\begin{tabular}{l} 
ABSTRACT \\
\hline Purpose: To investigate the effect of indocyanine green-mediated photo- \\
thrombosis on choroidal neovascularization secondary to angioid streaks. \\
Methods: Six eyes of 5 patients with an average age of 70 years were \\
diagnosed to have subfoveal choroidal neovascularization secondary to \\
angioid streaks. Therapy was indicated if choroidal neovascularization \\
was considered to be active, according to evidence of fluorescein leakage \\
on angiograms, as well as presence of intra- or subretinal fluid on optical \\
coherence tomography. Patients received photothrombosis at baseline \\
with retreatment as necessary at 3, 6 and 9 months follow-up. Fluorescein \\
leakage was assessed at 3, 6 and 9 months, along with foveal thickness \\
measured by optical coherence tomography. Indocyanine green angio- \\
graphy was performed initially and whenever retreatment was considered. \\
Retreatment was performed whenever there was evidence of increased \\
leakage on fluorescein angiograms at follow-up visits. Results: The mean \\
follow-up was 13.3 months. All eyes had at least 12 months follow-up. Two \\
eyes underwent retreatment. Three eyes had visual acuity improvement \\
and three eyes had stabilization. All patients showed less fluorescein \\
leakage on final angiograms and reduced foveal thickness upon optical \\
coherence tomography measurement. Conclusion: Photothrombosis is a \\
feasible procedure for choroidal neovascularization secondary to angioid \\
streaks. Lesion analysis showed anatomical improvement in most cases in \\
this series. Further studies are warranted to evaluate long-term results of \\
this treatment.
\end{tabular}

Keywords: Angioid streaks; Choroidal neovascularization/drug therapy; Indocyanine green; Photochemotherapy; Photosensitizing agents/therapeutic use; Lasers; Tomography, optical coherence

\section{INTRODUCTION}

The most serious ocular complication of angioid streaks is the occurrence of choroidal neovascularization (CNV) in $72 \%$ to $86 \%$ of patients. CNV becomes bilateral in approximately half of the cases within 18 months $^{(1-2)}$. The natural prognosis of $\mathrm{CNV}$ associated with angioid streaks is not favorable, as it usually involves scarring of the macula, resulting in loss of central vision and formation of large scotomata ${ }^{(3)}$. In these patients, macular damage leads to half of the patients becoming legally blind by the age of $50^{(1)}$.

Some studies demonstrated that laser photocoagulation of extrafoveal or juxtafoveal, well-demarcated CNV may ultimately result in less severe loss of vision compared with allowing a scar to form naturally ${ }^{(4-6)}$. However, management of lesions that extend under the fovea remains problematic. 
Poor preliminary results were obtained with most treatments reported to date, including surgical approaches ${ }^{(7-8)}$, transpupillary thermotherapy $\left(\right.$ TTT) ${ }^{(9)}$ and photodynamic therapy ${ }^{(10-15)}$. There are recent reports on the effect of angiogenesis inhibitors in patients with CNV secondary to angioid streaks ${ }^{(16-17)}$, but they lack long-term results.

Indocyanine green-mediated photothrombosis (IMP) has been used to treat $\mathrm{CNV}^{(18-21)}$. It consists of selective thrombosis of the choroidal neovascular membrane by laser delivery after intravenous injection of indocyanine green (ICG). In the present study, we investigated the efficacy of IMP for the treatment of CNV in a group of patients with angioid streaks.

\section{METHODS}

This study was approved by the Ethics Committee of the São Paulo Federal University, Brazil. It was a prospective, non-comparative interventional case series. Written informed consent was obtained from all patients. Six eyes of five patients, three male and two female, were treated. Their age ranged between 43 and 76 years, with a mean of 70 .

Patients with active subfoveal CNV associated with angioid streak findings were included. Therapy was indicated if CNV was considered to be active, according to evidence of fluorescein leakage on angiograms, as well as presence of intra- or subretinal fluid on optical coherence tomography (OCT). Angioid streaks were defined as reddish or brownish subretinal streaks radiating from the optic disc and possibly associated with other abnormalities of the fundus, such as orange-skin appearance or reticular retinal pigment epithelium dystrophy at the posterior pole ${ }^{(1)}$. Patients with signs of agerelated macular degeneration, such as confluent drusen, were excluded. Other exclusion criteria included patients with myopic fundus, intraocular inflammation and recent intraocular surgery (less than 3 months). Patients underwent complete ocular examination including medical history, bestcorrected visual acuity (BCVA), slit-lamp examination, tonometry, dilated fundus photographs, fluorescein and ICG angiograms and optical coherence tomography with Stratus OCT. ICG angiography was used to determine the lesion's greatest linear dimension (GLD) and ICG uptake at late phases (Figure 1).Visual acuity was measured in LogMAR units using ETDRS charts. Pretreatment examinations, considered as baseline for those included in the study, were completed within 7 days before treatment. All patients were referred to the Dermatology Department for systemic investigation and testing for pseudoxanthoma elasticum.

The laser delivery was performed with VISULAS 810s (Carl Zeiss Meditec AG, Jena, Germany), which consisted of a modified diode laser generating a wavelength of about $810 \mathrm{~nm}$ (near infrared), near the maximum absorption peak of ICG, coupled with a slit-lamp delivery system VISULINK TTT/U and a slit-lamp biomicroscope (SL 120, Carl Zeiss Meditec AG, Jena, Germany). Before any light application, a fundus contact

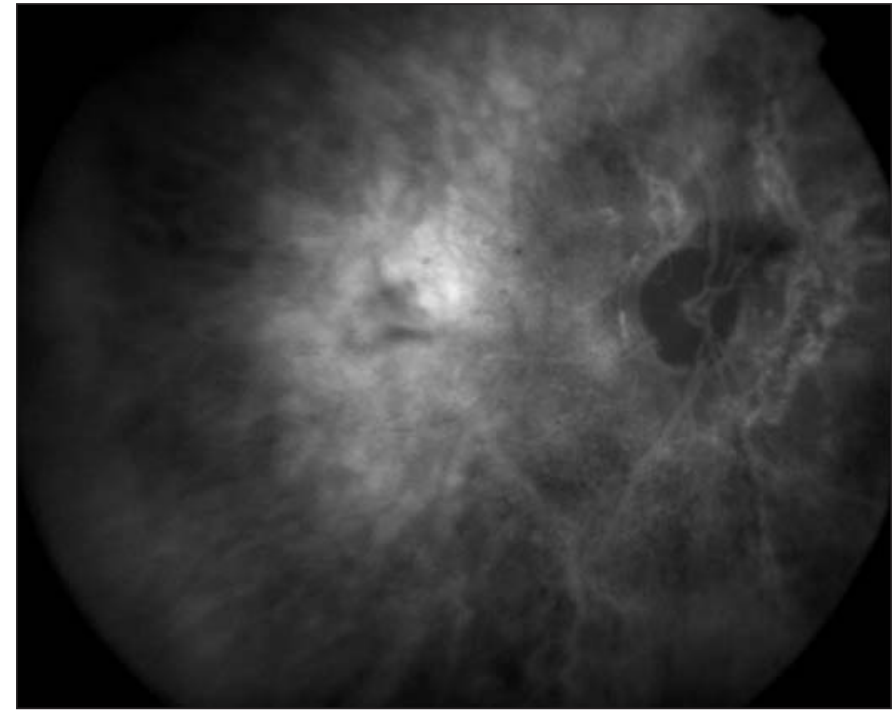

Figure 1 - Indocyanine green late frame angiogram showing ICG uptake by choroidal neovascular membrane. ICG angiograms were used to determine lesion size before treatment.

lens of 1.56 magnification (Mainster widefield, Ocular Instruments, Bellevue, USA) was placed on the cornea.

The treatment technique has been previously described ${ }^{(18)}$. Briefly, the patients underwent treatment with a total dose of $2 \mathrm{mg} / \mathrm{kg}$ of ICG solution (Ophthalmos, São Paulo, Brazil). For the procedure, a loading dose of a highly concentrated ICG solution ( $25 \mathrm{mg} / \mathrm{ml}$; approximately $1 \mathrm{mg} / \mathrm{kg}$ body weight) was administered as an intravenous bolus, followed immediately by a $5.0-\mathrm{ml}$ saline flush. At 30 minutes after the loading dose, a second intravenous injection of an identical solution was administered, followed by a 5.0-ml saline flush. Two minutes after the second flush infusion, a diode laser at $810 \mathrm{~nm}$ was used at an intensity of $3.0 \mathrm{~W} / \mathrm{cm}^{2}$ over 100 seconds to deliver light to the fundus. Spot size was set with a 500-micron margin on each side over GLD. At 20 minutes after the conclusion of the first laser application, a light dose with the same parameters was applied a second time to the exactly same position.

Patients were asked to return in one week for OCT evaluation and then at 3-month intervals until completion of a 12month follow-up period for visual acuity, complete ophthalmological examination, fluorescein angiography and OCT.

The criteria for re-treatment were based on the presence of leakage from $\mathrm{CNV}$ by fluorescein angiography or the presence of intraretinal or subretinal fluid by OCT at each follow-up visit. OCT was analyzed qualitatively and quantitatively, using the "retinal map" foveal thickness algorithm.

Outcome evaluations were functional (BCVA) and anatomical (clinical examination, fluorescein and ICG angiography patterns, as well as foveal thickness measured by OCT). Criteria for BCVA improvement or decrease were a difference of two or more ETDRS lines; change in BCVA of one line was considered stabilization.

Treatment was considered successful if BCVA improvement or stabilization was achieved within one-year follow-up. 


\section{RESULTS}

Six eyes of five patients were treated. All neovascular membranes were subfoveal.

Follow-up ranged from 52 to 80 weeks, with a mean of 56.6 weeks. A minimum of 12 months follow-up was obtained for all eyes. Tables 1 and 2 summarize baseline characteristics as well as changes in visual acuity and retinal thickness at each visit.

Dermatological results for pseudoxanthoma elasticum were negative in all patients.

The pretreatment best corrected visual acuity scores ranged from 20/80 to 20/800. Initial GLD ranged 2.47 to $6.75 \mathrm{~mm}$, with an average of $4.95 \mathrm{~mm}$.

Three eyes showed stabilization of visual acuity, while the other three eyes showed improvement of visual acuity, with post-treatment visual acuity ranging from 20/50 to 20/800. Among these three eyes, two eyes experienced three-line, and one eye, two-line improvement.

At the last follow-up visit, fluorescein leakage was decreased in all six eyes. Three eyes presented with a fibrous scar and three eyes progressed to some chorioretinal atrophy. Among these eyes with chorioretinal atrophy, two of them had a pigment alteration corresponding to the laser spot.

OCT analysis at the last follow-up visit showed decreased foveal thickness in all eyes (range 194-385 $\mu$ ), in comparison to pretreatment thickness (range 220-504 $\mu$ ). Two out of six treated eyes required two treatment sessions during the study period, while the other four required only one session. Retreatment was performed at 3 months in one eye and at 9 months in others. No adverse events were observed during ICG administration.

\section{DISCUSSION}

This study revealed that IMP for CNV secondary to angioid streaks attained a successful outcome, since 3 out of 6 eyes had BCVA improvement and 3 had stabilization. All eyes had diminished fluorescein leakage and retinal thickness at the last visit. IMP was shown to carry a favorable safety profile, since no eyes showed any decrease in visual acuity, and no patients experienced severe adverse effects. Nevertheless, many eyes had a poor visual acuity at the last visit. Poor prognosis in subfoveal neovascular membranes in angioid streaks may be attributed to collagen changes seen in these patients, as well as compromised adhesion of the retinal pigment epithelium (RPE) basal membrane to the inner portion of Bruch's membrane. Hence, choroidal neovascularization has little resistance to lateral growth under the RPE, resulting in large membranes ${ }^{(22)}$.

IMP using small volume infusions of a highly concentrated ICG solution and low irradiance with a large-spot $810 \mathrm{~nm}$ diode laser delivered by slit lamp has been shown to reduce vision loss in $\mathrm{CNV}^{(18-21)}$. To the best of our knowledge, there is no study in the literature reporting the results of IMP for CNV secondary to angioid streaks. Our study differs from a previously reported series ${ }^{(23)}$ in that the previous study used ingrowth site ICG-mediated photothrombosis (ISIMP), which is a different technique, and a different laser unit (Trimode-L; OPTO, São Carlos, Brazil) ${ }^{(24)}$.

The mechanisms of action of IMP are not completely known. It is hypothesized ${ }^{(18)}$ that a mixed type I (heat generation) and type II (singlet oxygen formation) photooxidation effect may explain the therapeutic effects of IMP, which is selective for neovascularization.

\begin{tabular}{|c|c|c|c|c|c|c|}
\hline ID & Age & Gender & Time of complaint & Status of other eye & Type of CNV & Greatest linear dimension at baseline $(\mathrm{mm})$ \\
\hline 1 & 43 & M & 1 month & Disciform & Classic & 3.58 \\
\hline \multirow[t]{2}{*}{2} & 74 & $\mathrm{~F}$ & 6 months & CNV & OD occult & 6.72 \\
\hline & & & & & OS occult & 6.75 \\
\hline 3 & 62 & M & 2 months & Normal & Occult & 4.40 \\
\hline 4 & 76 & M & 6 months & Disciform & Occult & 5.81 \\
\hline 5 & 65 & $\mathrm{~F}$ & 8 months & Polypoidal & Minimally classic & 2.47 \\
\hline
\end{tabular}

\begin{tabular}{|c|c|c|c|c|c|c|c|c|}
\hline ID & Eye & $\begin{array}{l}\text { Initial } \\
\text { BCVA }\end{array}$ & $\begin{array}{l}\text { Final } \\
\text { BCVA }\end{array}$ & $\begin{array}{l}\text { Initial foveal } \\
\text { thickness }\end{array}$ & $\begin{array}{c}\text { Final foveal } \\
\text { thickness }\end{array}$ & $\begin{array}{l}\text { Follow-up } \\
\text { (months) }\end{array}$ & Re-treat & Lesion analysis \\
\hline 1 & os & $20 / 800$ & $20 / 200$ & 504 & 315 & 12 & No & Fibrous scar \\
\hline 2 & OD & $20 / 400$ & $20 / 200$ & 411 & 251 & 20 & Yes $(9 \mathrm{~m})$ & Fibrous scar \\
\hline 2 & os & $20 / 100$ & $20 / 50$ & 304 & 227 & 12 & No & Fibrous scar \\
\hline 3 & OD & $20 / 800$ & $20 / 800$ & 493 & 194 & 12 & No & Chorioretinal atrophy ${ }^{\dagger}$ \\
\hline 4 & OD & $20 / 80$ & $20 / 63$ & 220 & 219 & 12 & Yes $(3 \mathrm{~m})$ & Chorioretinal atrophy \\
\hline 5 & OD & $20 / 200$ & $20 / 320$ & 255 & 181 & 12 & No & Chorioretinal atrophy ${ }^{\dagger}$ \\
\hline
\end{tabular}


Currently, other treatment modalities for subfoveal CNV secondary to angioid streaks have failed to show good results $^{(3-9)}$. Photodynamic therapy with verteporfin has been performed recently for this disease, although without strong evidence of efficacy ${ }^{(10-15)}$. In the latter studies, most of the eyes showed severe loss of vision after one year follow-up, where either a large disciform scar or progression of exudative disease was observed in these eyes. Results reported after intravitreal injection of bevacizumab are promising ${ }^{(16-17)}$, but longterm studies are needed.

Most patients included in this study had a poor visual acuity at baseline. Initial VA was equal to or worse than 20/200 in 4 out of 6 eyes. These eyes had large lesions with an average GLD of $4.95 \mathrm{~mm}$. Patients had visual complaints for long periods before treatment (range 1-8 months, average 3.8 months). All these facts may account for some poor visual acuity prognosis. Nevertheless, final BCVA was better than at the initial visit in three out of six eyes. Considering the poor prognosis associated with choroidal neovascularization secondary to angioid streaks, with most patients becoming legally blind by age $50^{(1)}$, these results must be highlighted.

The decreased retinal thickness and diminished fluorescein leakage that we found in all eyes of our study may also be interpreted as a natural history of the disease rather than the treatment effect. These results cannot be used as an evidence to demonstrate a positive effect of IMP on the arrest of disease progression because there was no control group in which we could see the natural history. Nevertheless, natural history is usually not associated with vision improvement such as that observed in this series.

On the other hand, two eyes developed some chorioretinal atrophy (Figure 2) corresponding to the laser spot, which can be considered photothermal injury ${ }^{(25)}$ and hence an adverse event. One of these eyes had a lower BCVA at the final visit, while the other showed stabilization. Thermal laser injuries are produced by high laser irradiances in brief exposures ranging from microseconds to several seconds. We analyzed retrospectively this adverse event and found no relation to any of the following pretreatment features that might have been responsible for this injury, such as patient age, time of complaint, the size of lesion, presence of subretinal blood, fluid, fibrosis, RPE and skin hyperpigmentation. It is accepted that, for some laser treatments such as TTT, laser irradiance varies significantly over the observed range of axial length ${ }^{(26)}$. Therefore, it is likely that in some hyperopic eyes with a short axial length the laser irradiance during TTT using an indirect condensing laser lens will be significantly higher than when using the same spot and the same laser power in an emmetropic eye. However, patients enrolled in this present study did not show significant differences in their axial lengths. For that reason, we could not attribute this adverse effect to a short axial length as may be the case with $\mathrm{TTT}^{(26)}$. Since all eyes underwent treatment using the same laser parameters, with variation concerning only spot size according to GLD, the answer to the question why some eyes underwent such atrophy remains obscure.

\section{CONCLUSION}

IMP is not yet an approved treatment, since it lacks multicenter randomized studies proving its efficacy. However, it has been proved to be a low-risk, well-tolerated treatment for CNV secondary to many diseases with a potential in achieving visual acuity stabilization and limiting central vision loss in different diseases complicated by CNV. This series comprised a small number of patients, which limits our conclusions. A multicenter IMP trial is currently underway, and it may help to establish the role of this treatment in the CNV scenario. If our preliminary data should be confirmed by the multicenter trial, IMP may turn out to be a good option for CNV treatment, with an excellent cost-effectiveness.

\section{ACKNOWLEDGEMENTS}

The authors thank ophthalmic technicians Gabriela Cardoso Tostes and Natalia Tamie Baba for the photographic and
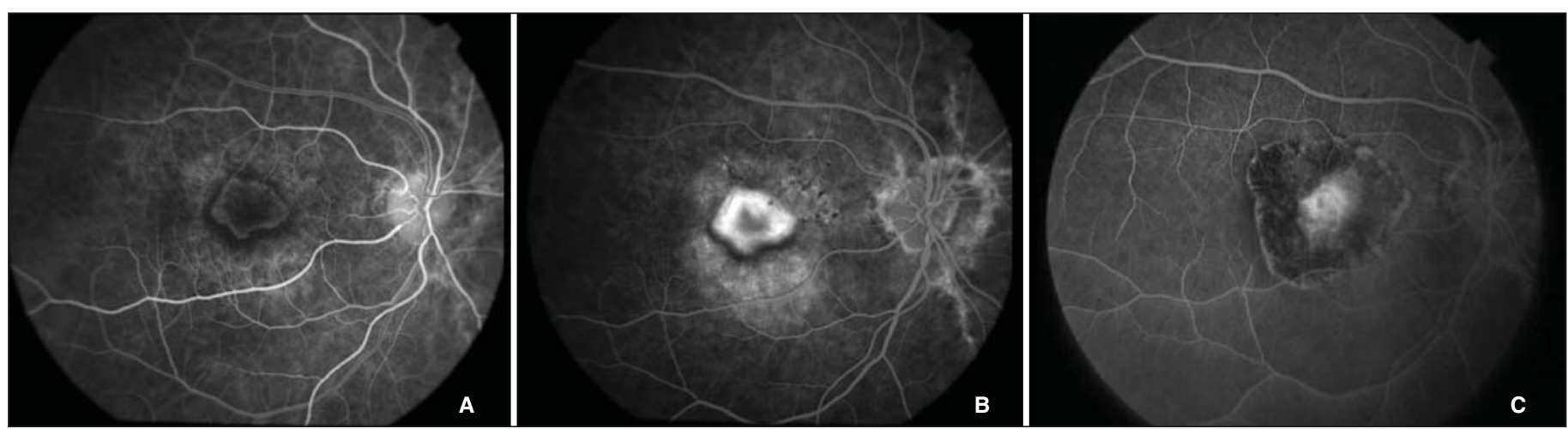

Figure 2 - Patient 5. After treatment, a fluorescein pattern was noted that was similar to a thermal laser scar. VA pretreatment was 20/200. Retinal thickness pretreatment was $255 \mu$. VA post-treatment was 20/320. Retinal thickness post-treatment was $181 \mu$. A) Fluorescein angiogram pretreatment - early frame; B) Fluorescein angiogram pretreatment - late frame; C) Fluorescein angiogram post-treatment. 
tomographic documentation. Dr. A. Leyva is also acknowledged for reading the manuscript.

\section{RESUMO}

Objetivo: Investigar os efeitos da fototrombose mediada por indocianina verde sobre a neovascularização de coróide secundária a estrias angióides. Métodos: Seis olhos de 5 pacientes com média de 70 anos de idade tinham o diagnóstico de neovascularização de coróide secundária a estrias angióides. $\mathrm{O}$ tratamento foi indicado para neovascularização de coróide ativa, avaliada pelo vazamento na angiofluoresceinografia e pela presença de fluido intra ou sub-retiniano pela tomografia de coerência óptica. Os pacientes receberam tratamento inicial com indocianina verde, e a seguir foram re-tratados conforme necessário com 3, 6 e 9 meses. Nessas ocasiões avaliava-se o vazamento e a espessura foveal. A angiografia com indocianina verde foi realizada inicialmente e sempre que o re-tratamento era considerado, nos casos em que havia aumento de vazamento pela angiofluoresceinografia nas visitas de seguimento. Resultados: O tempo médio de seguimento foi de 13,3 meses. Todos os olhos atingiram um seguimento de pelo menos 12 meses. Dois olhos foram submetidos a re-tratamento. Três olhos apresentaram melhora e três olhos apresentaram estabilização da acuidade visual. Todos os pacientes apresentaram diminuição final do vazamento e da espessura foveal. Conclusão: Indocianina verde é procedimento factível para o tratamento de neovascularização de coróide secundária a estrias angióides. A análise das lesões mostrou melhora anatômica na maioria dos casos desta série. Mais estudos são necessários para avaliar os resultados a longo prazo deste tratamento.

Descritores: Estrias angióides; Neovascularização coroidal/ quimioterapia; Verde de indocianina; Fotoquimioterapia; Agentes fotossensibilizantes/uso terapêutico; Lasers; Tomografia de coerência óptica

\section{REFERENCES}

1. Clarkson JG, Altman RD. Angioid streaks. Surv Ophthalmol. 1982;26(5):235-46

2. Piro PA, Scheraga D, Fine SL. Angioid streaks: natural history and visual prognosis. In: File SL, Owens SL, editors. Management of retinal vascular and macular disorders. Baltimore, Md: Williams \& Wilkins; 1983. p.136-9.

3. Schillings JS, Blach RK. Prognosis and therapy of angioid streaks. Trans Ophthalmol Soc UK. 1975;95(2):301-6.

4. Gelisken O, Hendrikse F, Deutman AF. A long-term follow-up study of laser coagulation of neovascular membranes in angioid streaks. Am J Ophthalmol. 1988;105(3);299-303.

5. Lim JI, Bressler NM, Marsh MJ, Bressler SB. Laser treatment of choroidal neovascularization in patients with angioid streaks. Am J Ophthalmol. 1993; 116(4):414-23.
6. Pece A, Avanza P, Galli L, Brancato R. Laser photocoagulation of choroidal neovascularization in angioid streaks. Retina. 1997;17(1):12-6.

7. Thomas MA, Dickinson JD, Melberg NS, Ibanez HE, Dhaliwal RS. Visual results after surgical removal of subfoveal choroidal neovascular membranes. Ophthalmology. 1994;101(8):1384-96

8. Fujii GY, Humayun MS, Pieramici DJ, Schachat AP, Au Eong KG, de Juan E Jr. Initial experience of inferior limited macular translocation for subfoveal choroidal neovascularization resulting from causes other than age-related macular degeneration. Am J Ophthalmol. 2001;131(1):90-100.

9. Ozdek S, Bozan E, Gürelik G, Hasanreisoglu B. Transpupillary thermotherapy for the treatment of choroidal neovascularization secondary to angioid streaks. Can J Ophthalmol. 2007;42(1):95-100.

10. Shaikh S, Ruby AJ, Williams GA. Photodynamic therapy using verteporfin for choroidal neovascularization in angioid streaks. Am J Ophthalmol. 2003; 135(1):16. Comment in: Am J Ophthalmol. 2003;136(3):580-2; author reply 582-3.

11. Menchini U, Virgili G, Introini U, Bandello F, Ambesi-Impiombato M, Pece A, et al. Outcome of choroidal neovascularization in angioid streaks after photodynamic therapy. Retina. 2004;24(5):763-71

12. Heimann H, Gelisken F, Wachtlin J, Wehner A, Völker M, Foerster MH, et al. Photodynamic therapy with verteporfin for choroidal neovascularization associated with angioid streaks. Graefes Arch Clin Exp Ophthalmol. 2005;243(11): $1115-23$.

13. Ladas ID, Georgalas I, Rouvas AA, Gotsis S, Karagiannis DA, Moschos M. Photodynamic therapy with verteporfin of choroidal neovascularization in angioid streaks: conventional versus early retreatment. Eur J Ophthalmol. 2005;15(1):69-73.

14. Browning AC, Chung AK, Ghanchi F, Harding SP, Musadiq M, Talks SJ, et al. Verteporfin photodynamic therapy of choroidal neovascularization in angioid streaks: one-year results of a prospective case series. Ophthalmology. 2005;112(7):1227-31.

15. Arias L, Pujol O, Rubio M, Caminal J. Long-term results of photodynamic therapy for the treatment of choroidal neovascularization secondary to angioid streaks. Graefes Arch Clin Exp Ophthalmol. 2006; 244(6):753-7.

16. Lommatzch A, Spital G, Trieschmann M, Pauleikhoff D. [Intraocular application of bevacizumab for the treatment of choroidal neovascularization secondary to angioid streaks]. Ophthalmologe. 2007;104(4):325-8. German.

17. Teixeira A, Moraes N, Farah ME, Bonomo PP. Choroidal neovascularization treated with intravitreal injection of bevacizumab (Avastin) in angioid streaks. Acta Ophthalmol Scand. 2006;84(6):835-6.

18. Farah ME, Cardillo JA, Luzardo AC, Calucci D, Williams GA, Costa RA. Indocyanine green mediated photothrombosis for the management of predominantly classic choroidal neovascularization caused by age related macular degeneration. Br J Ophthalmol. 2004;88(8):1055-9.

19. Arevalo JF, Garcia RA, Mendoza AJ. Indocyanine green-mediated photothrombosis with intravitreal triamcinolone acetonide for subfoveal choroidal neovascularization in age-related macular degeneration. Graefes Arch Clin Exp Ophthalmol. 2005;243(11):1180-5.

20. Navajas EV, Costa RA, Farah ME, Cardillo JA, Bonomo PP. Indocyanine green-mediated photothrombosis combined with intravitreal triamcinolone for the treatment of choroidal neocascularization in serpiginous choroiditis. Eye. 2003;17(5):563-6.

21. Costa RA, Navajas EV, Farah ME, Calucci D, Cardillo JA, Scott IU. Polypoidal choroidal vasculopathy: angiographic characterization of the network vascular elements and a new treatment paradigm. Prog Retin Eye Res. 2005; 24(5):560-86.

22. Gass JD. Stereoscopic atlas of macular diseases: diagnostic and treatment. St Louis, Missouri: Mosby; 1997. Chapter 2, Pathophysiologic and histopathologic bases for interpretation of fluorescein angiography; p.19-47.

23. Costa RA, Calucci D, Cardillo JA, Farah ME. Selective occlusion of subfoveal choroidal neovascularization in angioid streaks by using a new technique of ingrowth site treatment. Ophthalmology. 2003;110(6):1192-203.

24. Roizenblatt R, Farah ME, Castro J, Cardillo JA, Costa RA, Roizenblatt J. Diode laser modifications for treatment of choroidal neovascularization. Laser Med Sci. 2003;18(1):43-4.

25. Mainster MA, Stuck BE, Brown J Jr. Assessment of alleged retinal laser injuries. Arch Ophthalmol. 2004;122(8):1210-7.

26. Stur M, Ansari-Shahrezaei S. The effect of axial length on laser spot size and laser irradiance. Arch Ophthalmol. 2001;119(9):1323-8. 